\title{
Effective self-regulated science learning through multimedia-enriched skeleton concept maps
}

Citation for published version (APA):

Marée, T. J., Van Bruggen, J., \& Jochems, W. M. G. (2013). Effective self-regulated science learning through multimedia-enriched skeleton concept maps. Research in Science \& Technological Education, 31(1), 16-30. https://doi.org/10.1080/02635143.2013.782283

\section{DOI:}

10.1080/02635143.2013.782283

Document status and date:

Published: 01/01/2013

Document Version:

Other version

Please check the document version of this publication:

- A submitted manuscript is the version of the article upon submission and before peer-review. There can be important differences between the submitted version and the official published version of record. People interested in the research are advised to contact the author for the final version of the publication, or visit the DOI to the publisher's website.

- The final author version and the galley proof are versions of the publication after peer review.

- The final published version features the final layout of the paper including the volume, issue and page numbers.

Link to publication

\section{General rights}

Copyright and moral rights for the publications made accessible in the public portal are retained by the authors and/or other copyright owners and it is a condition of accessing publications that users recognise and abide by the legal requirements associated with these rights.

- Users may download and print one copy of any publication from the public portal for the purpose of private study or research.

- You may not further distribute the material or use it for any profit-making activity or commercial gain

- You may freely distribute the URL identifying the publication in the public portal.

If the publication is distributed under the terms of Article 25fa of the Dutch Copyright Act, indicated by the "Taverne" license above, please follow below link for the End User Agreement:

https://www.ou.nl/taverne-agreement

Take down policy

If you believe that this document breaches copyright please contact us at:

pure-support@ou.nl

providing details and we will investigate your claim.

Downloaded from https://research.ou.nl/ on date: 26 Apr. 2023 
Title

Effective self-regulated science learning through multimedia-enriched skeleton concept maps

Authors

Ton J. Maree

JanM. van Bruggen

Wim M.G. Jochems

Affiliations

Eindhoven University of Technology, The Netherlands

Open University of The Netherlands, The Netherlands

Eindhoven University of Technology, The Netherlands

\section{APA}

Marée, A.J., Bruggen, van, J.M. \& Jochems, W.M.G. (2013). Effective self-regulated science learning through multimedia-enriched skeleton concept maps. Research in Science \& Technological Education, 31(1), 16-30.

DOI

https://doi.org/10.1080/02635143.2013.782283

\section{Abstract}

This study combines work on concept mapping with scripted collaborative learning. Purpose: The objective was to examine the effects of self-regulated science learning through scripting students' argumentative interactions during collaborative 'multimedia-enriched skeleton concept mapping' on meaningful science learning and retention.

Programme description: Each concept in the enriched skeleton concept map (ESCoM) contained annotated multimedia-rich content (pictures, text, animations or video clips) that elaborated the concept, and an embedded collaboration script to guide students' interactions. Sample: The study was performed in a Biomolecules course on the Bachelor of Applied Science program in the Netherlands. All first-year students (N=93, 31 women, 62 men, aged 17-33 years) took part in this study.

Design and methods: The design used a control group who received the regular course and an experimental group working together in dyads on an ESCoM under the guidance of collaboration scripts. In order to investigate meaningful understanding and retention, a retention test was administered a month after the final exam.

Results: Analysis of covariance demonstrated a significant experimental effect on the Biomolecules exam scores between the experimental group and the control, and the difference between the groups on the retention test also reached statistical significance.

Conclusions: Scripted collaborative multimedia ESCoM mapping resulted in meaningful understanding and retention of the conceptual structure of the domain, the concepts, and their relations. Not only was scripted collaborative multimedia ESCoM mapping more effective 
than the traditional teaching approach, it was also more efficient in requiring far less teacher guidance. 